\title{
断熱材の簡便な熱伝導率測定技術の開発
}

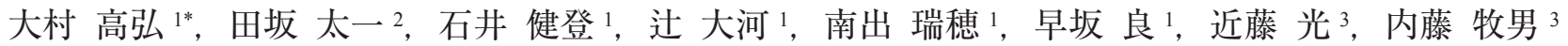

\section{Development of Simple Method to Measure Thermal Conductivity of Thermal Insulations}

\author{
Takahiro Ohmura $^{1 *}$, Taichi Tasaka ${ }^{2}$, Kento Ishii ${ }^{1}$, Taiga Tsuji ${ }^{1}$, Mizuho Minamide ${ }^{1}$, Ryo Hayasaka ${ }^{1}$ \\ Akira Kondo ${ }^{3}$ and Makio Naito ${ }^{3}$
}

Received 19 September 2018; Accepted 7 November 2018

\begin{abstract}
Recently, the practical use of high performance insulation materials such as nanoparticles insulation material or the vacuum insulation material has been spreading to various kinds of industrial fields including industrial furnaces, buildings, home electric appliances, thermal or cold insulation boxes. However, it is very difficult to measure the thermal conductivity. Because uniform temperature gradient for applying Fourier's low must be achieved in the test specimen. To solve this issue, we have proposed a new method to measure the thermal conductivity of specimens which includes ununiformed temperature gradient areas, and have developed an apparatus with simple structure. In this paper, we have applied this method for the measurement until $400^{\circ} \mathrm{C}$. As the result, the thermal conductivity of the ceramics fiber insulation, the calcium silicate, and the nanoparticle material insulations agreed within $\pm 10 \%$ for the previous studies in the temperature range from $100^{\circ} \mathrm{C}$ to $400^{\circ} \mathrm{C}$. The uncertainty of the measured values also made clear this method is reliable.
\end{abstract}

Keywords: Fourier's low, Guarded hot plate, Thermal conductivity, Thermal insulation, Uncertainty.

\section{1. 緒言}

近年の世界的規模の省エネルギー活動により,さまざ まなタイプの高性能断熱材, たとえば真空断熱材やナノ 粒子断熱材, 発泡系断熱材など, 静止空気の熱伝導率よ りも低い值を持った断熱材が次々と開発されている $[1-$ 4]。それに伴い, 開発者が夕イムリーにそして簡便に熱 伝導率を測定できる環境が望まれるようになった。しか しながら，現在のところ市販の熱伝導率測定装置は高価 であり, また, 構造も複雑なため自作も難しい状況であ る。たとえば，世界的にもっともよく使用されている保 護熱板法（Guarded Hot Plate method: GHP 法）[5]では, 試験体内部に一様な温度勾配を作り出すことでフーリエ の法則を適用できるようにしているが，これを実現する ために試験体表面の加熱ヒータを, 主熱板と保護熱板に

\footnotetext{
1 和歌山工業高等専門学校

( T 644-0023 和歌山県御坊市名田町野島 77)

National Institute of Technology, Wakayama College

(77, Noshima, Nada, Gobo, Wakayama 644-0023, Japan)

2 一般財団法人 建材試験センター

（ ₹ 340-0015 埼玉県草加市稲荷 5-21-20）

Japan Testing Center for Construction Materials

(5-21-20, Inari, Soka, Saitama 340-0015, Japan)

3 大阪大学 接合科学研究所

（† 567-0047 大阪府茨木市美穂ヶ丘 11-1）

Joining and Welding Research Institute, Osaka University

(11-1, Mihogaoka, Ibaraki, Osaka 567-0047, Japan)

* Corresponding Author oomura@wakayama-nct.ac.jp
}

分離する構造をとっている。その結果, 構造が複雑とな り温度制御も難しい装置になっている。また, 近年, 注 目されるようになった周期加熱法[6]による測定では, 正 確な熱拡散率測定を実現するために任意波形発生器や直 流電源などを必要とし, さらに比熱を別途測定して熱伝 導率に換算する必要がある。このように, 従来の断熱材 の熱伝導率測定では, 正確な測定を実現するために装置 が複雑化し, 測定には煩雑さを要するため, 材料開発者 が簡単に熱伝導率を測定できる状態ではなくなっている。 そこで筆者らは，簡便で自作も容易に可能であり，な おかつ, 従来の方法に劣らない測定精度を持つ熱伝導率 測定方法の開発に着手した。試験体内を流れる熱量を厚 さ方向とそれ以外に流れる熱量に分離することで, 高い 測定精度を確保しつつ, 測定装置の構造は市販の板状 ヒータに試験体を積み重ね, 試験体の各部の温度を測定 するだけの簡単な測定方法を開発した。すでに, $50^{\circ} \mathrm{C}$ か ら $180^{\circ} \mathrm{C}$ の温度範囲において, 保護熱板法や周期加熱法 による測定結果との比較を試み, $\pm 10 \%$ 程度で一致するこ とを確認した[7]。

本研究では, 本法を基礎としてさらに高温度域での熱 伝導率の測定を試みた。具体的には，3 種類の試験体を 用いて最高温度 $100^{\circ} \mathrm{C}$ から $400^{\circ} \mathrm{C}$ までの範囲での測定を 行い, 得られた結果をほかの測定方法による結果と比較 することによって, その妥当性を検討した。さらに, 提 案する測定方法における測定結果の不確かさについても 定量的解析を行った。 


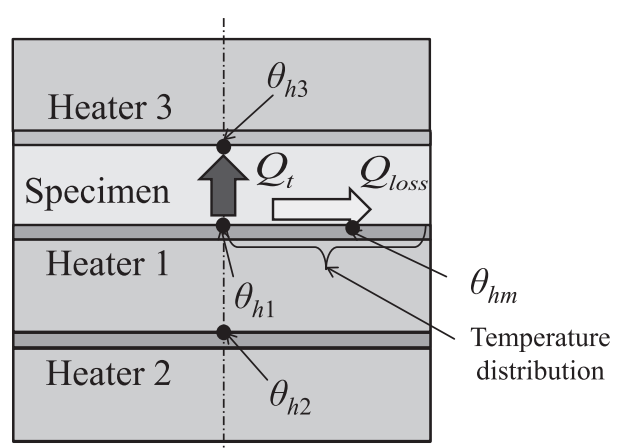

Fig. 1 Cross section of measurement system [7]

\section{2. 測定原理}

Fig. 1 に示すように, ヒータ 1 とヒータ 2 の温度が等 しくなる $\left(\theta_{h 1}=\theta_{h 2}\right)$ ようにヒータ 2 の温度を制御する と, ヒータ 1 で発生した熱量 $Q$ がすべて試験体内に流入 すると仮定できる。さらに, その熱量 $Q$ が, 試験体の厚 さ方向（低温側へ向かう方向）に流れる熱量 $Q_{t}$ と, 試験 体内部で厚さ方向以外の方向へ放散する熱量 $Q_{\text {loss }}$ の和に なっていると仮定すると，

$$
Q=Q_{t}+Q_{\text {loss }}
$$

と表すことができる。

また, 試験体の厚さ方向に流れる熱量 $Q_{t}$ に対しては, フーリエの法則が適用できると仮定して,

$$
Q_{t}=\lambda_{t} \frac{\Delta \theta}{d} S
$$

とする。ここで, $d$ は試験体の厚さ $[\mathrm{m}], Q_{t}$ は試験体の厚 さ方向に流れる熱量[W], $S$ は熱流面積 $\left[\mathrm{m}^{2}\right], \Delta \theta$ は試験体 の温度差 $\left(=\theta_{h 1}-\theta_{h 3}\right)\left[{ }^{\circ} \mathrm{C}\right], \lambda_{t}$ は試験体の厚さ方向の熱伝 導率 $[\mathrm{W} /(\mathrm{m} \cdot \mathrm{K})]$ である。

一方, ヒータ 1 から試験体へ流入する熱量 $Q$ (ヒータ 1 で発生した熱量）については， $Q$ がフーリエの法則と 同じ形の式で表されるものとした。すなわち, 試験体内 の温度勾配 $\Delta \theta / d$ と熱流面積 $S$ に対して比例すると仮定 し，その係数を $\lambda_{c}$ とすれば,

$$
Q=\lambda_{c} \frac{\Delta \theta}{d} S
$$

と表すことができる。ここで, $\lambda_{c}$ の単位は $[\mathrm{W} /(\mathrm{m} \cdot \mathrm{K})]$ であ る。

さらに熱損失 $Q_{\text {loss }}$ は, 面内方向に生じる代表温度差 を $\Delta \theta_{\text {loss }}$ とすれば, 面内方向の熱コンダクタンス $H$ との 積で表され,

$$
Q_{\text {loss }}=H \cdot \Delta \theta_{\text {loss }}
$$

となる。Eq. (1)に Eqs. (2)〜(4) を代入することで,

$$
\lambda_{c}=\lambda_{t}+a \cdot \Theta
$$

を得る。ここで, 係数 $a$ を Eq. (6) のように抄き，また, 試験体の厚さ方向の温度差に対する面内方向の代表温度 差との比を Eq. (7) に示す $\Theta （$ 無次元温度）で表した。

$$
\begin{aligned}
& a=\frac{H \cdot d}{S} \\
& \Theta=\frac{\Delta \theta_{\text {loss }}}{\Delta \theta}
\end{aligned}
$$

Eq. (5) より, 無次元温度 $\Theta$ と係数 $\lambda_{c}$ は, 直線関係をもつ ことがわかる。

面内方向の温度差 $\Delta \theta_{\text {loss }}$ については, 平面内の温度分 布関数 $f(r)$ を決定し, これを使って面内平均温度を求め, 高温面中央における温度 $\theta_{h 1}$ との差をとることで $\Delta \theta_{l o s s}$ を 決定した。すなわち, 高温面の中央を原点にとり, その 平面内の温度分布を測定する。そのときの原点から側面 までの範囲における平均温度 $\theta_{h \mathrm{~m}}$ は,

$$
\theta_{h m}=\frac{1}{r_{e}} \int_{0}^{r_{e}} f(r) \mathrm{d} r
$$

であり，本測定方法では $\Delta \theta_{\text {loss }}$ を，

$$
\Delta \theta_{\text {loss }}=\theta_{h 1}-\theta_{h m}
$$

とした。ここで， $r$ は試験体面内の中央を原点として, 試験体側面へ向かう方向の距離を表している。実際の測 定では, 温度分布関数 $f(r)$ として $r$ の三次関数を使用し た。

本測定方法では, 試験体上下の温度差 $\Delta \theta$ を複数回変 化させて Eq. (3)に示す係数 $\lambda_{c}$ を測定し, そのときの試験 体表面の温度分布から $\Delta \theta_{\text {loss }}$ を求めて無次元温度 $\Theta$ を導 き, 横軸に無次元温度 $\Theta$, 縦軸に Eq. (3) の係数 $\lambda_{c}$ をプ ロットして近似直線を描く。その直線の切片が, 試験体 の厚さ方向の熱伝導率 $\lambda_{t}$ となる。Fig. 2 にデータをプロッ トしたイメージを示す。この測定方法では，できるだけ 熱損失が大きいと考えられる面内の温度分布を測定する ことが好ましいと考えられ, 本測定系では Fig. 1 に示す ヒータ 1 と試験体との接触面の温度分布を測定した。

\section{3. 測定装置}

Fig. 3 に，測定部の模式図を示す[7]。図に示すように 下から順にヒータ 2, ヒー夕 1 , 試験体, ヒー夕 3 と重敉 るだけの構造であり, 周囲に囲いはなく, 室温に曝され ている状態である。既報[7]では $50^{\circ} \mathrm{C} \sim 180^{\circ} \mathrm{C}$ の温度範囲 での測定を可能とするため, ヒー夕 3 をラバーヒータと して冷却性能を高める構造としたが, 本研究では $100^{\circ} \mathrm{C}$ から $400^{\circ} \mathrm{C}$ の温度範囲をターゲットにしているため, 3 つのヒータをすべて同じセラミックスヒータとした。そ のヒータの厚さは, 内部に埋め込まれたヒー夕線と断熱 部分を含めて約 $50 \mathrm{~mm}$ である。ヒータ 2 の下側には, 厚 さ約 $20 \mathrm{~mm}$ のポリスチレンフォームを 2 枚重ねて設置し た。試験体のサイズは約 $300 \mathrm{~mm} \times 300 \mathrm{~mm}$ である。

試験体の表面温度測定には, 素線径 $0.32 \mathrm{~mm}$ の K タイ プ熱電対（シースではなく素線の状態）を使用した。設 置した位置を Fig. 4 に×印で示す。Fig. 4 (a) では中心に 1 つ, Fig. $4(b)$ では中心から $x$ 軸方向と $y$ 軸方向に $37.5 \mathrm{~mm}$ 間隔で 3 つずつ, これらとは逆方向の $75 \mathrm{~mm}$ の 


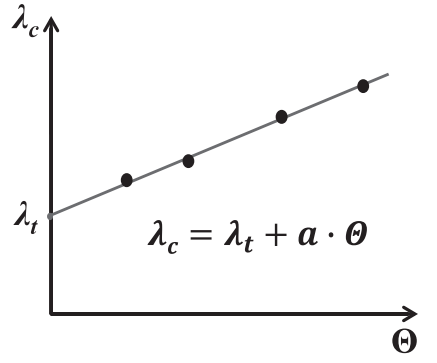

Fig. 2 Image of proposed measurement method [7]

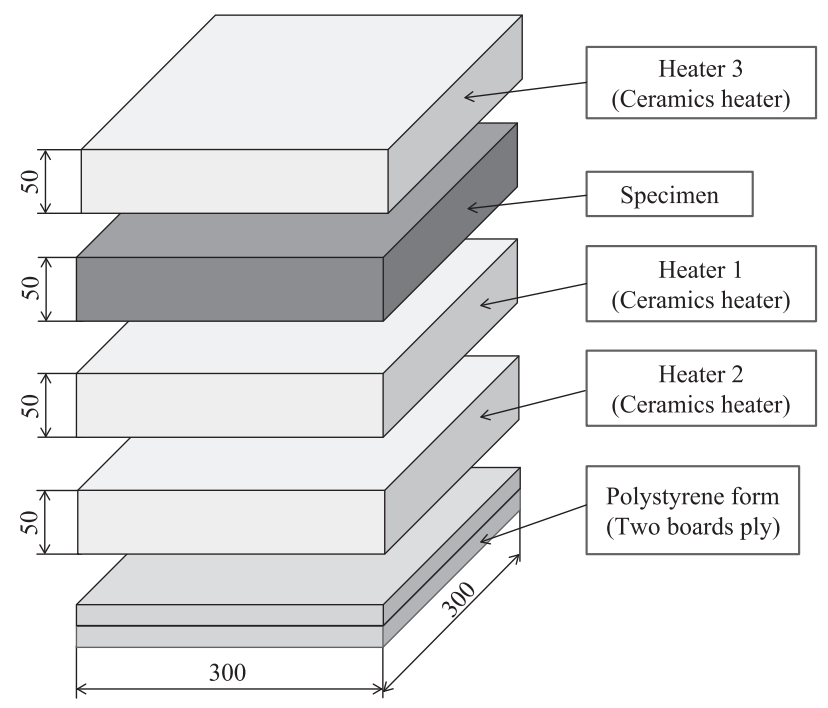

Fig. 3 Measurement part of new apparatus [7]

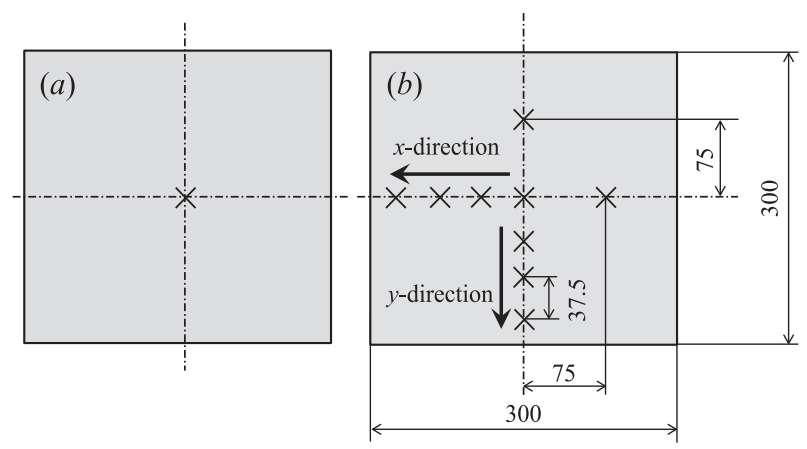

Fig. 4 Positions of thermocouples [7]

位置に 1 つずつ, 計 9 つの熱電対を配置した。試験体の 高温面と低温面, ヒータ 1 とヒータ 2 の接触面には, Fig. 4 (b) に示す配置で設置し, ヒー夕 2 とポリスチレン フォームの接触面には Fig. 4 (a) に示す配置で設置した。 熱電対は, 試験体の表面に接触できるように直接配置し たが，その設置によりヒータと試験体の間に隙間が生じ る可能性があるため, ヒータの表面側に厚さ $2 \mathrm{~mm}$ 程度 のセラミックスブランケットを敷いて, クッション材の 役割を担わせた。ヒー夕 1 で発生する電力 $Q$ は，あらか じめヒータの抵抗を測定しておき，加熱中にヒー夕にか かる電圧を測定することで求めた。

温度制御装置はチノー製 SY2111-00，各部の温度を測 定するデータロガーは GRAPHTEC midi LOGGER GL900 をそれぞれ使用した。

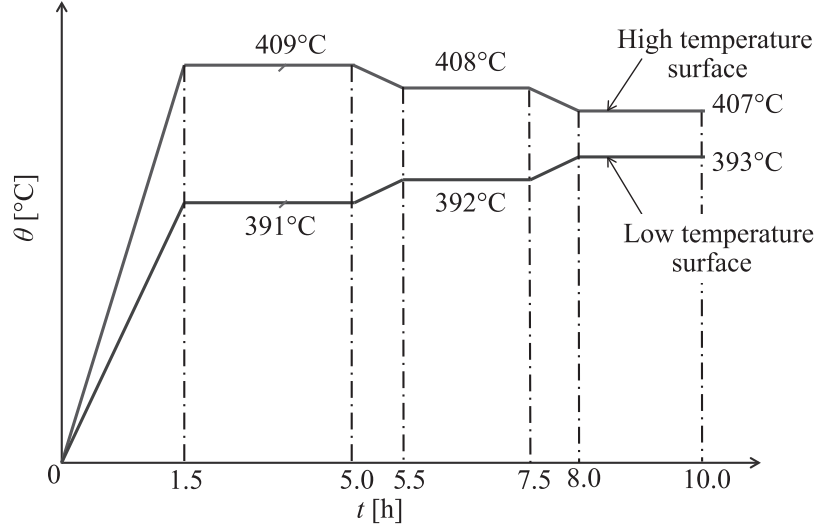

Fig. 5 Example of heating profiles at $400^{\circ} \mathrm{C}$

\section{4. 測定条件}

本測定では，測定のための昇温を Fig. 5 に示すような

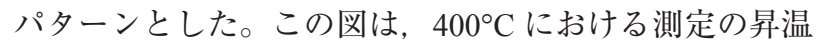
パターンの一例であるが, 試験体にかける温度差 $\Delta \theta$ を 3 段階 $\left(18^{\circ} \mathrm{C}, 16^{\circ} \mathrm{C}, 14^{\circ} \mathrm{C}\right)$ に変化させており, 試験体 内部の温度が定常に達して, 測定が終了するまでの温度 保持時間を, $\Delta \theta$ が $18^{\circ} \mathrm{C}, 16^{\circ} \mathrm{C}, 14^{\circ} \mathrm{C}$ に対して, それぞ れ約 3.5 時間, 約 2.0 時間, 約 2.0 時間とした。各 $\Delta \theta$ の 間隔を $2^{\circ} \mathrm{C}$ としたのは, $\Delta \theta$ を変化させる際のヒー夕発熱 量をできるだけ小さくすることで温度制御の振れを抑え， 短時間で温度を安定させるためである。なお，本測定で

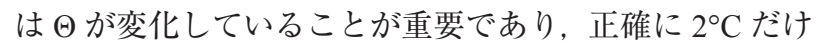
異なる温度差 $\Delta \theta$ が必要とされているわけではない。し たがって, $\Delta \theta$ が $2^{\circ} \mathrm{C}$ 程度異なっていれば $\Theta$ が明らかに 変化するため, ここで使用している温度制御装置掞よび データロガーで十分な精度の測定が可能となる。

ヒータ 1 で発生する電力量, 打よびすべての位置にお ける温度測定の時間間隔は 1 分であり, $\lambda_{c}$ を求めるため に使用する温度測定の時間領域は，各温度でできるだけ 安定していて, 変化の少ない部分の約 1 時間（測定点と して 60 点程度）とした。

\section{5. 試験体}

アルミナおよびシリカを主成分とした結晶質アルミナ 短繊維から成るセラミックファイバー断熱材（かさ密度 約 $\left.180 \mathrm{~kg} / \mathrm{m}^{3}\right)$ と, ゾノトライト結晶を主成分とするケイ 酸カルシウム保温材 (JIS A 9510, 1 号-13 品, かさ密度 約 $\left.120 \mathrm{~kg} / \mathrm{m}^{3}\right)$ ，フュームドアルミナをベースとしたナノ 粒子断熱材（質量比でフュームドアルミナ $60 \%$, セラ ミック瀻維 $15 \%, \mathrm{SiC}$ 粒子 $25 \%$ で構成される多孔質断熱 材）の3つを試験体として測定した。それぞれの寸法と かさ密度を Table 1 に示す。ここで示す厚さは, 試験体 の 4 側面の中央付近をそれぞれ 1 回ずつ測定した平均値 (全 4 回測定の平均) である。また, セラミックスファイ バー断熱材については試験体厚さを三段階に変化させて, 最初に厚さ $36.5 \mathrm{~mm}$ の試験体（試験体 C) を測定し, 次 に同試験体を厚さ $20.9 \mathrm{~mm}$ (試験体 B）まで薄くしてか 
Table 1 Test Specimens

\begin{tabular}{ccccc}
\hline Specimen & & $\begin{array}{c}\text { Apparent } \\
\text { density }\left[\mathrm{kg} / \mathrm{m}^{3}\right]\end{array}$ & Mass [g] & Dimension [mm] \\
\hline Ceramics fiber & A & 183 & 600 & $300 \times 300 \times 16.2$ \\
insulation & B & 180 & 338 & $300 \times 300 \times 20.9$ \\
Calcium silicate & $\mathrm{C}$ & 183 & 267 & $300 \times 300 \times 36.5$ \\
$\begin{array}{c}\text { Fibrous fumed } \\
\text { alumina compacts }\end{array}$ & 129 & 233 & $300 \times 300 \times 20.0$ \\
\hline
\end{tabular}

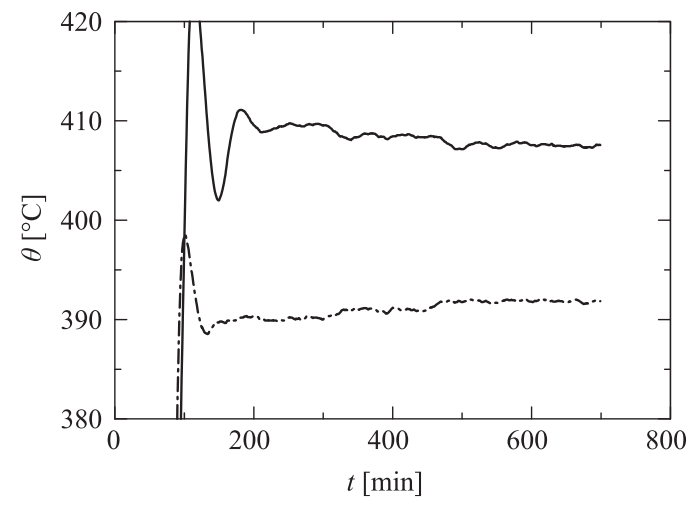

Fig. 6 Measurement example of temperature profiles at $400^{\circ} \mathrm{C}$

ら再度測定し, 最後に厚さ $16.2 \mathrm{~mm}$ （試験体 A）まで薄 くして熱伝導率を測定した。

ナノ粒子断熱材は，摩砕式ミルによって製造したもの であり [2,3]，大きさ $150 \mathrm{~mm} \times 100 \mathrm{~mm}$ の試験片を 6 つ用 意し， $300 \mathrm{~mm} \times 300 \mathrm{~mm}$ となるように配置して測定した。 ただし，試験体設置面 $(300 \mathrm{~mm} \times 300 \mathrm{~mm})$ の中央に試験 体同士の接触面が来ないように，中央に試験体 $(150 \mathrm{~mm}$ $\times 100 \mathrm{~mm} ）$ を 3 つ並べ，その左右に半分に切断した試験 体（75 mm×100 mm）をそれぞれ接触させて並べた。接 触面には接着剤は使用しなかったが，目視のレベルで接 触面に大きな隙間がないことを確認した。Table 1 に示す 值は, 6 つの試験片の平均值である。

なお，試験体表面の粗さは熱伝導率測定結果に影響を およぼす可能性があるが，本研究で使用した試験体表面 の粗さは, 日本工業規格[5]の規定（試験体表の平滑度 は，試験体厚さの $2 \%$ 以下）に収まっていることから, 測定結果には影響しないと判断した。

\section{6. 実験結果と考察}

\section{1 セラミックファイバー断熱材の測定結果}

セラミックファイバー断熱材を試験体として, $400^{\circ} \mathrm{C}$ において測定したときの温度場の一例を Fig. 6 に示す。 実線が試験体の高温面の温度，一点鎖線が低温面の温度 であり, 各段階で約 60 分（測定点 60 点）の範囲のデー 夕を使用して熱伝導率を求めた。

さらに，試験体の高温面内における温度分布の一例を

Fig. 7 に示す。図中の丸印は, Fig. 4 に示す $y$ 軸方向の温 度分布であり, 実線は 3 次関数による近似曲線である。 一方, 三角印は Fig. 4 の $x$ 軸方向の温度分布であり, 破

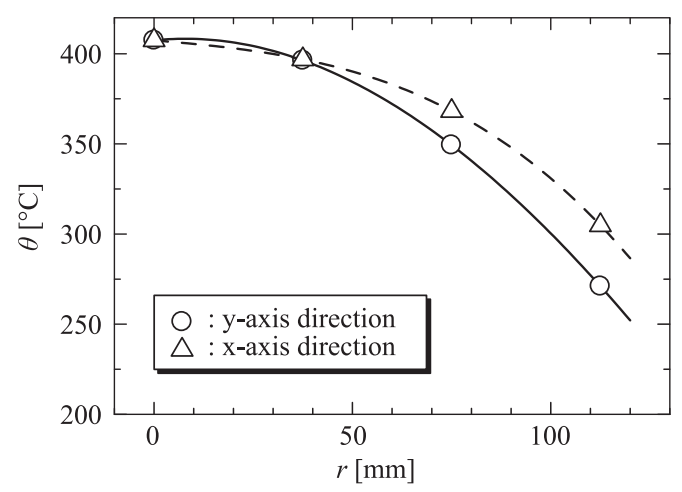

Fig. 7 Temperature distributions of high temperature surface of Ceramics fiber insulation at $400^{\circ} \mathrm{C}$

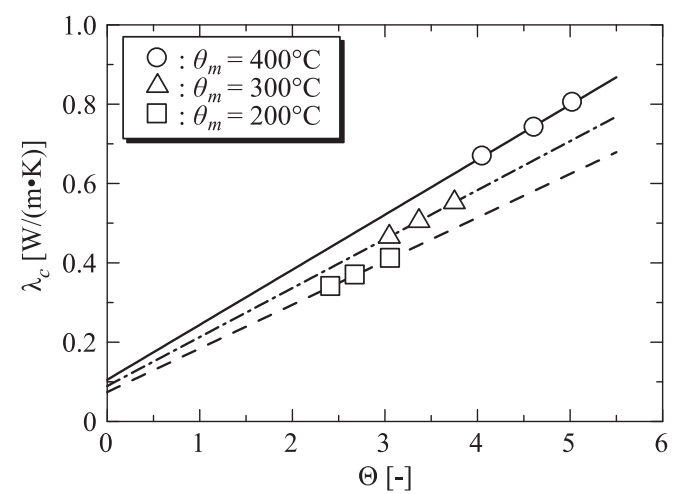

Fig. 8 Relation between $\Theta$ and $\lambda_{c}$ obtained by measuring Ceramics fiber insulation.

線は同じく 3 次関数による近似曲線である。本実験では, Fig. 4 に示す $y$ 軸方向の温度分布を使って厚さ方向の熱 伝導率 $\lambda_{t}$ を算出した。

Fig. 8 に, 各測定温度における $\Theta$ と $\lambda_{c}$ の関係の一例 (試験体 C の測定結果) を示す。ここで, 丸, 三角, 四 角の印が, それぞれ試験体平均温度 $400^{\circ} \mathrm{C}, 300^{\circ} \mathrm{C}, 200^{\circ} \mathrm{C}$ で測定した結果を表しており，同様に，実線，一点鎖線， 破線が, それぞれ試験体平均温度 $400^{\circ} \mathrm{C}, 300^{\circ} \mathrm{C}, 200^{\circ} \mathrm{C}$ の結果に対する近似直線を表している。各温度の近似曲 線は，以下の通りである。

$$
\begin{aligned}
& 200^{\circ} \mathrm{C}: \lambda_{c}=0.110 \Theta+0.0741 \\
& 300^{\circ} \mathrm{C}: \lambda_{c}=0.124 \Theta+0.0893 \\
& 400^{\circ} \mathrm{C}: \lambda_{c}=0.139 \Theta+0.1050
\end{aligned}
$$

また, Fig. 8 中の $\theta_{m}$ は Eq. (8) で示す試験体の平均温度で あり, 各温度差 $\Delta \theta$ で得られた試験体のそれぞれの高温 面中央温度 $\theta_{h 1}$ と低温面中央温度 $\theta_{h 3}$ の平均值を全平均 した結果である。

$$
\theta_{m}=\frac{\sum_{m=1}^{n}\left(\theta_{h 1}+\theta_{h 3}\right)_{m} / 2}{n}
$$

ここで, $m$ は, 厚さ方向の熱伝導率 $\lambda_{t}$ を得ようとしてい る各温度において, 無次元温度 $\Theta$ を変えた測定一つ一つ 


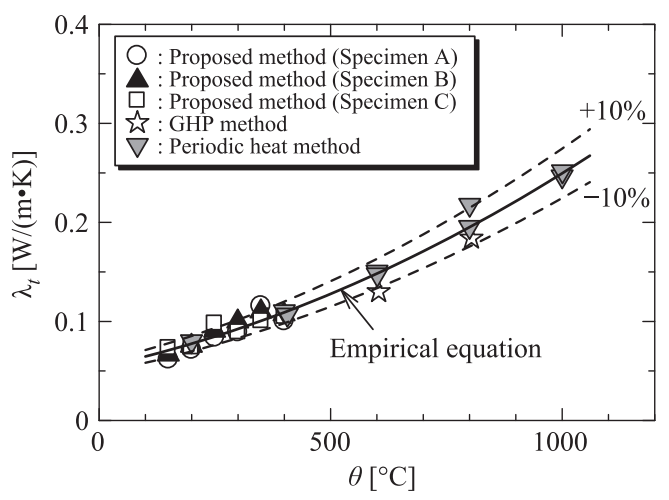

Fig. 9 Thermal conductivity of Ceramics fiber insulations

を識別するための数字であり $n$ はその温度における全 測定回数である。すなわち, $n$ は $\Theta$ を変えた全回数であ る。Eqs. (10)〜 (12)に示す各温度における一次直線の切片 が，それぞれの温度における厚さ方向の熱伝導率 $\lambda_{t}$ とな る。

Fig. 9 にセラミックファイバー断熱材の熱伝導率測定 結果を示す。横軸は試験体の平均温度 $\theta\left(=\theta_{m}\right)$, 縦軸は 厚さ方向の熱伝導率 $\lambda_{t}$ である。眓中の丸印, 三角印, 四 角印が，それぞれ試験体 $\mathrm{A}$ ，試験体 B, 試験体 C の測定 結果であり，星印が保護熱板法（GHP 法）による測定結 果, 逆三角印は周期加熱法[6]による測定の結果である。 実線は，これら 5 種類のデータすべてを使って，最小二 乗法により求めた近似曲線であり,

$$
\lambda_{t}=7.69 \times 10^{-8} \theta^{2}+1.13 \times 10^{-4} \theta+5.10 \times 10^{-2}
$$

である。さらに，破線は実線に対する $\pm 10 \%$ を示してい る。また，保護熱板法による測定では，本測定で使用し た試験体と同じ製造ロットの母材から直径 $300 \mathrm{~mm}$ ，厚 さ約 $25 \mathrm{~mm}$ に切り出されたものを測定している。周期加 熱法でも，GHP 法に使用したものと同じロットから約 $125 \mathrm{~mm} \times 125 \mathrm{~mm} \times 25 \mathrm{~mm}$ に切り出したものを 2 枚重ねて 測定している。

Fig. 9 より，5種類の測定結果がおおよそ $\pm 10 \%$ 以内で 一致していることがわかる。したがって，本測定結果は， 異なる測定方法である GHP 法や周期加熱法による結果 とほぼ一致することが示され，適切な精度で測定できて いることがわかる。また, 試験体の厚さが $16 \mathrm{~mm}$ から $37 \mathrm{~mm}$ の範囲で変化しても, ほとんど測定精度に影響し ないこともわかった。

試験体が厚くなるにつれて，試験体側面からの熱損失 $Q_{\text {loss }}$ が増大し, 厚さ方向へ流れる熱量 $Q_{t}$ が検出できない ほど小さくなってしまう，あるいはほぼすべての熱量が 試験体側面から放出されてしまうなどにより，Eq. (2)が 成立しない可能性が考えられる。しかしながら，今回対 象とした試験体の熱伝導率レベルであれば, $40 \mathrm{~mm}$ 程度 の厚さまで測定可能であることがわかった。

\section{2 ケイ酸カルシウム保温材の測定結果}

Fig. 10 にケイ酸カルシウム保温材の熱伝導率測定結果 を示す。横軸は試験体平均温度 $\theta$, 縦軸は試験体の厚さ

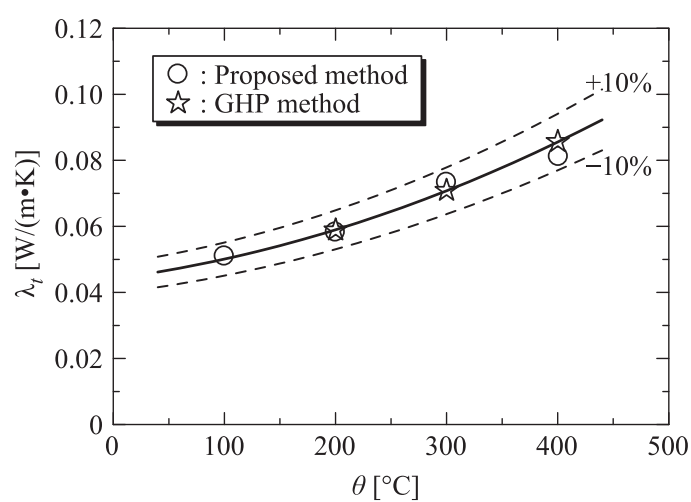

Fig. 10 Thermal conductivity of Calcium silicate insulation

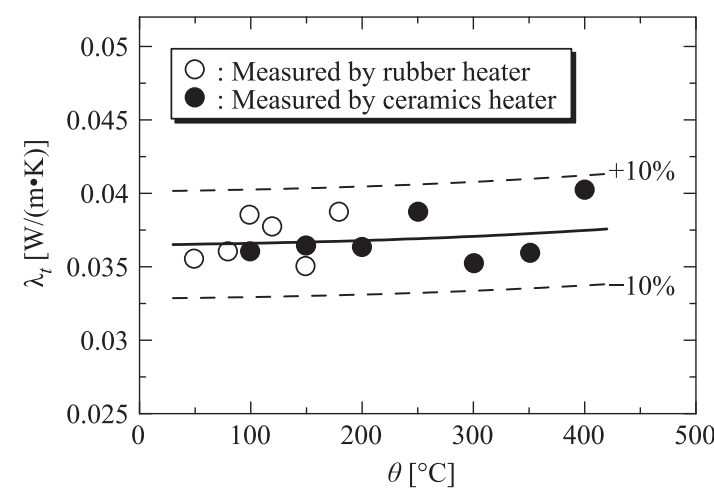

Fig. 11 Thermal conductivity of Fibrous fumed silica compact

方向の熱伝導率 $\lambda_{t}$, 丸印は本測定方法による結果, 星印 は GHP 法による測定結果であり，実線はGHP 法による 測定結果から最小二乗法により求めた近似曲線であり, 次式で表される。

$$
\lambda_{t}=1.47 \times 10^{-7} \theta^{2}+4.46 \times 10^{-5} \theta+4.42 \times 10^{-2}
$$

Fig. 10 より, 本測定による結果は, 保護熱板法により得 られた近似曲線と $100^{\circ} \mathrm{C}$ から $400^{\circ} \mathrm{C}$ の温度範囲で $\pm 10 \%$ 以内で一致していることがわかる。

\section{3 ナノ粒子断熱材の測定結果}

Fig. 11 にナノ粒子断熱材の熱伝導率測定結果を示す。 白丸印は，既報[7]で測定したヒータ 3 がラバーヒータの 場合であり，黒丸印は本報で測定した結果である。さら に実線は，フュームドアルミナを用いたナノ粒子断熱材 の熱伝導率推定式として, すでに提案されている次式[3] による值を示している。

$$
\lambda=4.4 \times 10^{-5} \rho+\frac{1.8 \times 10^{-9}}{\rho} T^{3}+0.0131
$$

また，破線は実線に対する $\pm 10 \%$ 示している。Fig. 11 より，3者が $10 \%$ 以内で一致していることがわかる。

\section{7. 不確かさの評価}

本測定方法は, Fig. 8 に示したように近似直線を作っ て, その外挿により試験体の厚さ方向の熱伝導率 $\lambda_{t}$ を求 めるものである。そのため, 直線の傾きが測定誤差の大 きな要因の一つになる。そこで, 不確かさを以下のよう に検討した。 
Eq. (1) から Eq. (7) の関係から,

$$
\begin{aligned}
& \frac{Q \cdot d}{\Delta \theta \cdot S}=\lambda_{t}+\frac{H \cdot d}{\Delta \theta \cdot S} \Delta \theta_{\text {loss }} \\
& \therefore \quad \lambda_{t}=\frac{d}{\Delta \theta \cdot S}\left(Q-H \cdot \Delta \theta_{\text {loss }}\right)
\end{aligned}
$$

を得る。したがって, 本測定方法の不確かさ $u\left(\lambda_{t}\right)$ は, 試 験体内に流入する熱量 $Q$, 試験体厚さ $d$, 熱流面積 $S$, 試 験体の厚さ方向の温度差 $\Delta \theta$, 面内方向の熱コンダクタ ンス $H$, 面内方向の代表温度差 $\Delta \theta_{\text {loss }}$ などの測定の不確 かさからなり，

$$
\begin{aligned}
& u^{2}\left(\lambda_{t}\right)=\left(\frac{\delta \lambda_{t}}{\delta d}\right)^{2} u^{2}(d)+\left(\frac{\delta \lambda_{t}}{\delta \Delta \theta}\right)^{2} u^{2}(\Delta \theta)+\left(\frac{\delta \lambda_{t}}{\delta S}\right)^{2} u^{2}(s) \\
& +\left(\frac{\delta \lambda_{t}}{\delta Q}\right)^{2} u^{2}(Q)+\left(\frac{\delta \lambda_{t}}{\delta H}\right)^{2} u^{2}(H)+\left(\frac{\delta \lambda_{t}}{\delta \Delta \theta_{\text {loss }}}\right)^{2} u^{2}\left(\Delta \theta_{\text {loss }}\right)+\sum_{n} E_{n}
\end{aligned}
$$

と表すことができる。ここで， $u(d)$ は試験体厚さ $d$ を測 定したときの不確かさ， $u(\Delta \theta)$ は試験体にかける温度差 $\Delta \theta$ を測定したときの不確かさ， $u(S)$ は試験体の熱流面積 $S$ を測定したときの不確かさ， $u(Q)$ は試験体に流入する 熱量 $Q$ を測定したときの不確かさ， $u(H)$ は試験体の面内 方向の熱コンダクタンス $H$ を測定したときの不確かさ, $u\left(\Delta \theta_{\text {loss }}\right)$ は試験体内のある面における面内方向の温度差 $\Delta \theta_{\text {loss }}$ を測定したときの不確かさであり， $\Sigma E_{n}$ は，これら 以外の測定に関わる不確かさである。たとえば，試験体 の表面温度測定のために使用している熱電対を介しての 熱流入出による不確かさや, Fig. 1 に示すヒータ 1 とヒー 夕 2 に無視できないほどの大きな温度差が生じた場合の 不確かさなどが考えられる。

本測定では, 熱コンダクタンス $H$ を直接測定していな いため, Eq. (19) の右辺第 5 項を無視でき, さらに, 熱 電対は十分に細く, ヒータ 1 とヒータ 2 の温度差も, 試 験体にかかる温度差に比べて十分小さな值になるように 温度制御されているなど, そのほかの不確かさを無視で きるとすれば, Eq. (18) と Eq. (19)より,

$$
\begin{aligned}
& \left(\frac{u\left(\lambda_{t}\right)}{\lambda_{t}}\right)^{2}=\left(\frac{u(d)}{d}\right)^{2}+\left(\frac{u(\Delta \theta)}{\Delta \theta}\right)^{2} \\
& +\left(\frac{u(S)}{S}\right)^{2}+\left(\frac{Q}{Q-H \cdot \Delta \theta_{\text {loss }}}\right)^{2}\left(\frac{u(Q)}{Q}\right)^{2} \\
& +\left(\frac{H \cdot \Delta \theta_{\text {loss }}}{Q-H \cdot \Delta \theta_{\text {loss }}}\right)^{2}\left(\frac{u\left(\Delta \theta_{\text {loss }}\right)}{\Delta \theta_{\text {loss }}}\right)^{2}
\end{aligned}
$$

を得る。

実際の測定例（セラミックファイバー断熱材）を基に 不確かさを以下に見積もった。

(1) Eq. (20)の第 1 項（試験体厚さ）：最小読取り值 $0.05 \mathrm{~mm}$ のノギスにより 4 箇所計測し, その平均を試験 体厚さとしており, $u_{d}=0.05 \mathrm{~mm}$ とするともっとも薄い 試験体 $(16 \mathrm{~mm})$ の場合でも,

$$
\frac{u_{d}}{d}=\frac{0.05}{16} \cong 0.003
$$

と見積もれる。
(2) Eq. (20)の第 2 項 (温度差) $: 0.1^{\circ} \mathrm{C}$ まで測定可能 なデータロガーにより計測しており, もっとも温度差が 小さい $14^{\circ} \mathrm{C}$ の場合, 高温面と低温面の両面間の温度差 を計算していることを考慮して

$$
\frac{u_{\Delta \theta}}{\Delta \theta}=\frac{\sqrt{0.1^{2}+0.1^{2}}}{14} \cong 0.01
$$

と見積もれる。

(3) Eq. (20)の第 3 項 (面積) : 1 辺の長さ $L$ に対して, 不確かさが $\delta L$ あるとすると,

$$
\frac{u_{S}}{S}=\frac{(L+\delta L)^{2}-L^{2}}{L^{2}} \cong 2 \frac{\delta L}{L}
$$

となり, 最小読取り值 $0.05 \mathrm{~mm}$ のノギスによる測定で, $L=300 \mathrm{~mm}$, 試験体の少々の歪みを考慮して $\delta L=1 \mathrm{~mm}$ とすれば,

$$
\frac{u_{S}}{S} \cong 2 \frac{1}{300}=0.007
$$

と見積もれる。

(4) Eq. (20)の第 4 項 (熱量)：第 4 項を以下のように 変形した。すなわち, Eqs. (1)〜(4)より,

$$
\begin{aligned}
\frac{Q}{Q-H \cdot \Delta \theta_{\text {loss }}} & =\frac{Q}{Q_{t}} \\
& =\frac{\lambda_{c}}{\lambda_{t}} \cong \frac{0.8}{0.1} \cong 8
\end{aligned}
$$

となり, ヒータの発熱量は, 読み值の $0.5 \%$ 程度の精度を 有する電力計で測定しているので,

$$
\frac{Q}{Q-H \cdot \Delta \theta_{\text {loss }}} \frac{u(Q)}{Q}=8 \times 0.005=0.04
$$

を得る。

(5) Eq. (20)の第 5 項 (温度差)：第 5 項を以下のよう に変形して不確かさを見積もった。すなわち, Eqs. (1)〜 (7)より,

$$
\frac{H \cdot \Delta \theta_{\text {loss }}}{Q-H \cdot \Delta \theta_{\text {loss }}}=\frac{a \cdot \Theta}{\lambda_{t}}
$$

となり, Eq. (12) から $a=0.139$, Fig. 8 より $\Theta=5$ とし， Fig. 7 より $\Delta \theta_{\text {loss }}$ を $80^{\circ} \mathrm{C}$, Fig. 9 より $400^{\circ} \mathrm{C} の \lambda_{t}$ を $0.1 \mathrm{~W} /$ $(\mathrm{m} \cdot \mathrm{K})$ として, 試験体の面内温度測定の不確かさ $u(\Delta \theta$ loss $)$ を $0.5^{\circ} \mathrm{C}$ 程度とすると，

$$
\frac{H \cdot \Delta \theta_{\text {loss }}}{Q-H \cdot \Delta \theta_{\text {loss }}} \frac{u\left(\Delta \theta_{\text {loss }}\right)}{\Delta \theta_{\text {loss }}}=\frac{0.139 \times 5}{0.1} \times \frac{0.5}{80}=0.043
$$

と見積もれる。

したがって, Eqs. (21)〜(27)の結果を Eq. (20)に代入す ると，

$$
\left(\frac{u\left(\lambda_{t}\right)}{\lambda_{t}}\right)^{2}=0.003^{2}+0.01^{2}+0.007^{2}+0.04^{2}+0.043^{2}=0.00358
$$

となり, よって本測定の $u\left(\lambda_{t}\right) / \lambda_{t}$ は, 
$\frac{u\left(\lambda_{t}\right)}{\lambda_{t}}=0.060$

と見積もることができる。包合係数 $k$ を 2 とすれば,

$\frac{U}{\lambda_{t}}=\frac{k \times u\left(\lambda_{t}\right)}{\lambda_{t}}=0.120$

となる。よって，たとえば本測定方法において得られた 熱伝導率 $\lambda_{t}$ が $0.1 \mathrm{~W} /(\mathrm{m} \cdot \mathrm{K})$ であれば, その拡張不確かさ は $0.012 \mathrm{~W} /(\mathrm{m} \cdot \mathrm{K})$ となる。

3 種類の試験体の測定結果は，ほかの測定方法による 結果や推定式との結果などと $\pm 10 \%$ 以内にることから, 各測定方法の不確かさを考慮すると，本測定結果は，十 分信頼できるものであると考えられる。

\section{8. 結 言}

試験体内部の温度場の一部に不均一な温度勾配がある
ような場合でも, 熱伝導率を精度よく測定できる簡便な 構造の測定方法を用いて, $400^{\circ} \mathrm{C}$ まで測定温度範囲を広 げて熱伝導率の測定を行った。その結果, 以下の結論を 得た。

（1）セラミックファイバー断熱材, ケイ酸カルシウム保 温材，ナノ粒子断熱材のそれぞれの熱伝導率を測定 したところ，異なる測定方法による結果や推定式に よる結果などと $\pm 10 \%$ 以内で一致することがわかっ た。

（2）測定結果の不確かさ評価を行ったところ, 熱伝導率 $\lambda_{t}$ とその拡張不確かさの比は約 $12 \%$ であった。

[謝辞] デンカ株式会社殿および日本ケイカル株式会社殿 からは断熱材を提供頂いた。ここに記して謝意を表す。

\section{Nomenclature}

$\begin{array}{llr}a & : \text { defined by Eq. (6) } & {[\mathrm{W} /(\mathrm{m} \cdot \mathrm{K})]} \\ d & : \text { thickness of specimen } & {[\mathrm{m}]} \\ H & : \text { thermal conductance in the plane direction of } \\ & \text { specimen } & {[\mathrm{W} / \mathrm{K}]} \\ k & : \text { coverage factor } & {[-]} \\ m & : \text { number to identify measurement at a temperature } \\ & & \\ n & : \text { total number of measurement at a temperature } & {[-]} \\ Q_{t} & : \text { amount of heat } & {[\mathrm{W}]} \\ Q_{l o s s} & : \text { amount of heat in direction of thickness } & {[\mathrm{W}]}\end{array}$

[W]

$S \quad$ : heat flow area $\quad\left[\mathrm{m}^{2}\right]$

$T \quad$ : absolute temperature [K]

$u(d) \quad$ : uncertainty of measuring thickness of specimen

[m]

$u(H) \quad$ : uncertainty of measuring thermal conductance in the plane direction of specimen

$[\mathrm{W} / \mathrm{K}]$

$u(\mathrm{Q}) \quad$ : uncertainty of measuring amount of heat $\quad[\mathrm{W}]$

$u(\mathrm{~S}) \quad$ : uncertainty of measuring heat flow area $\quad\left[\mathrm{m}^{2}\right]$

$u(\Delta \theta) \quad$ : uncertainty of measuring differential temperature in thickness direction

$u(\Delta \theta l o s s)$ : uncertainty of measuring differential temperature in plane direction

$u\left(\lambda_{t}\right) \quad$ : uncertainty of thermal conductivity in direction of thickness of specimen $\quad[\mathrm{W} /(\mathrm{m} \cdot \mathrm{K})]$

$\begin{array}{llr}\theta & : \text { temperature } & {\left[{ }^{\circ} \mathrm{C}\right]} \\ \theta_{h 1} & : \text { temperature at center of high temperature surface }\end{array}$ of specimen

$\theta_{h 3} \quad:$ temperature at center of low temperature surface of specimen

$\left[{ }^{\circ} \mathrm{C}\right]$

$\theta_{m} \quad:$ mean temperature decided by Eq. (13)

$\Delta \theta \quad:$ differential temperature of specimen in thickness $\begin{array}{ll}\text { direction } & {\left[{ }^{\circ} \mathrm{C}\right]}\end{array}$

$\Delta \theta_{\text {loss }} \quad$ : differential temperature in plane direction $\quad\left[{ }^{\circ} \mathrm{C}\right]$

$\Theta \quad$ : dimensionless number defined by Eq. (7) $\quad[-]$ $\lambda \quad:$ thermal conductivity $[\mathrm{W} /(\mathrm{m} \cdot \mathrm{K})]$ $\lambda_{c} \quad:$ coefficient in Eq. (3) [W/(m.K)]

$\lambda_{t} \quad:$ thermal conductivity in direction of thickness of specimen

$[\mathrm{W} /(\mathrm{m} \cdot \mathrm{K})]$

bulk density

$\left[\mathrm{kg} / \mathrm{m}^{3}\right]$

$\Sigma E_{n} \quad$ : other uncertainty

$\left[\mathrm{W}^{2} /\left(\mathrm{m}^{2} \cdot \mathrm{K}^{2}\right)\right]$

\section{References}

[1] T. Ohmura, T. Tasaka, M. Ogawa, M. Akoshima, T. Fujimoto, Estimation method of thermal conductivity of core part in vacuum insulation panel, Netsu Bussei 31 (2016) 9297.

[2] T. Ohmura, I. Abe, Y. Ito, K. Sato, H. Abe, M. Naito, Development and evaluation of nanoporous materials, J. Soc. Powder Technol., Japan 46 (2003) 461-466.

[3] T. Ohmura, Y. Ito, I. Abe, H. Abe, M. Naito, Fabrication and evaluation of thermal insulation materials by using nanoparticle/fiber composites for high temperature, J. Soc. Powder Technol., Japan 46 (2003) 806-812.
[4] M. Ohshima, Polymer foaming for innovative heat insulator, J. the Heat Transfer Society of Japan 49, 208 (2010) 47-51.

[5] JIS A 1412-1: Test method for thermal resistance and related properties of thermal insulations-Part 1: Guarded hot plate apparatus (2006).

[6] T. Ohmura, M. Tsuboi, The thermal conductivity test by a cyclic heat method, Netsu Bussei 13 (1999) 264-270.

[7] T. Ohmura, T.-W. Lian, R. Hayasaka, A. Kondo, M. Naito, Measurement method of thermal conductivity in ununiformed temperature field, Netsu Bussei 31 (2017) 166173. 